\title{
PENGARUH PEMBERIAN EKSTRAK ETANOL DAUN BINAHONG (Anredera scandens (L.) Moq.) TERHADAP HISTOPATOLOGI HATI MENCIT JANTAN GALUR Balb/c YANG DIINDUKSI DENGAN KARBON TERTRAKLORIDA
}

\author{
L. P. Dessy Hariyanti ${ }^{1}$, A. A. N. Wisnu Wardhana ${ }^{1}$, N. K. Sri Indriyani ${ }^{1}$, I. A. P. Yudia Putri ${ }^{1}$ \\ ${ }^{1}$ Jurusan Farmasi Fakultas Matematika Dan Ilmu Pengetahuan Alam Universitas Udayana \\ Korespondensi: Luh Putu Dessy Hariyanti \\ Jurusan Farmasi Fakultas Matematika Dan Ilmu Pengetahuan Alam Universitas Udayana \\ Jalan Kampus Unud-Jimbaran, Jimbaran-Bali, Indonesia 80364 Telp/Fax: 0361-703837 \\ Email : hariyantidessy29@gmail.com
}

\begin{abstract}
ABSTRAK
Penggunaan obat-obatan salah satunya parasetamol dalam jangka panjang dapat memberikan efek samping kerusak sel hati. Tujuan penelitian ini untuk mengetahui pengaruh pemberian ekstrak etanol A. scandens (L.) Moq terhadap histologi hati mencit galur Balb/C yang terinduksi karbon tetraklorida. Penelitian ini menggunakan mencit galur Balb/c berjumlah 35 ekor dibagi menjadi 7 kelompok. Pengamatan histopatologi sel hati pada 48 jam setelah perlakuan.Persentase kerusakan hati dianalisis dengan data skoring perubahan histopatologi dan analisis non parametrik Kruskal-Wallis test, dan dilanjutkan dengan analisis Mann Whitney. Hasil penelitian menunjukan adanya perlindungan terhadap hati terlihat dari turunnya skor kerusakan hati dan meningkatkannya persen kerusakan hati pada kelompok perlakuan.
\end{abstract}

Kata kunci : Anredera scandens, histopatologi, flavonoid, hati, hepatoprotektor

\section{PENDAHULUAN}

Pengobatan alternatif dengan obat herbal karena obat herbal memiliki efek samping yang lebih rendah jika dibandingkan dengan obat sintesis. Pada dasarnya sebagian besar penyakit diawali dengan oksidasi yang berlebihan dalam tubuh (Winarsi, 2007).

Hati didalam tubuh manusia merupakan kelenjar yang paling besar, sebagai pusat metabolisme tubuh dengan fungsi yang sangat kompleks memiliki berat kurang lebih 2,5\% berat badan orang dewasa (Noer, dkk., 1996). Menurut Data WHO, penyakit hati di Indonesia yang disebabkan oleh virus, termasuk dalam peringkat endemik yang tinggi, Kerusakan hati juga dapat disebabkan oleh mikroorganisme maupun senyawa kimia (Linawati, 2003). Hepatitis merupakan penyakit yang disebabkan oleh virus hepatitis. Hepatitis A, B dan C yang sering dijumpai. Manifestasi penyakit hepatitis dapat mengakibatkan hepatitis akut, hepatitis kronik, bahkan dapat mengakibatkan kanker hati (DepKes RI, 2007). Senyawa kimia radikal yang dapat merusak hati seperti parasetamol, bentazepam, ranitidin, dan danasol (Cinthya, 2012; Lucena et al, 2008). Obat yang sering digunakan yaitu salah satunya Parasetamol. Penggunaan dalam jangka panjang dapat memberikan efek samping kerusak sel hati yang disebabkan oleh metabolit yang terbentuk dari parasetamol dengan isoenzim sitokrom $\mathrm{P} 450$ yaitu $\mathrm{N}$-asetil-p-benzoquinon imin (NAPQI) (Klaasen and Watkins, 2003).

Pengembangan obat herbal sangat mendukung dalam hal ini sehingga terus dilakukan pengembangan obat herbal dengan cara memanfaatkan kekayaan negara Indonesia secara maksimal, salah satunya adalah Binahong yang mengandung metabolit sekunder salah satunya yaitu flavonoid yang berpotensi sebagai antioksidan (Lestari, D., et al., 2015). Penelitian sebelumnya menunjukkan bahwa $A$. scandens mempunyai aktivitas sebagai antibakteri, antiinflamasi, antitukak, antiluka bakar (Fitria, 2009; Samirana, 2010; Karismawan, 2013 ), diperkuat dengan kekerabatan $A$. scandens yang masih satu genus dengan $A$. cordifolia yang memiliki aktivitas sebagai hepatoprotektor terhadap hati tikus yang diinduksi $\mathrm{CCl} 4$ (Orbayinah dan Adhita, 2008).

Berdasarkan ilmu kemotaksonomi, tanaman yang masih satu genus memiliki senyawa dan aktivitas yang hampir sama. Maka dari itu, perlunya dilakukan penelitian lebih lanjut guna mengetahui pengaruh pemberian ekstrak etanol A. scandens sebagai hepatoprotektor, sehingga dilakukan penelitian untuk mengetahui pengaruh ekstrak etanol yang diberikan terhadap 
histopatologi kerusakan hati mencit yang diinduksi karbon tetraklorida.

\section{BAHAN DAN METODE}

\subsection{Bahan}

Serbuk Daun binahong ( Hargobinangun, Yogyakarta) ; Etanol $70 \%$ (Bratacem); CCl4 ; olive oil (food grade); Tween 80 (Merck ${ }^{\circledR}$ ); Curcuma ${ }^{\circledR F C T}$; Aquadest, BNF $10 \%$ (Merck $\left.{ }^{\circledR}\right)$.

\subsection{Alat}

Rotary evaporator $\left(\right.$ Eyela $\left.{ }^{\circledR}\right)$; mikroskop cahaya (Olympus CX21®)

\subsection{Hewan Uji}

Hewan uji adalah 30 ekor mencit jantan galur $\mathrm{balb} / \mathrm{C}$ berumur 2-3 bulan dengan berat 20 30 gram

\subsection{Prosedur Kerja}

2.4.1 Pembuatan ekstrak etanol daun Binahong (Anredera scandens (L.) Moq.)

500 gram dimaserasi dengan 5 liter etanol $70 \%$ selama \pm 24 jam dan beberapa kali diaduk, kemudian disaring untuk memisahkan antara ampas dan filtratnya. Residu dimaserasi kembali dengan cara yang sama dengan pengulangan 2 kali menggunakan pelarut 3 liter. Filtrat yang diperoleh hasil maserasi ditampung menjadi satu kemudian diuapkan menggunakan alat Rotary evaporator pada suhu $68 \mathrm{oC}$ sehingga didapatkan ekstrak kental.

\subsubsection{Preparasi Larutan dan Larutan Uji}

Penyiapan 5\% Tween 80 dengan cara 5 $\mathrm{mL}$ Tween 80 dipipet setelah itu dimasukkan ke dalam labu ukur $100 \mathrm{~mL}$ ditambahkan akuades sampai $100 \mathrm{~mL}$. Larutan Curcuma ${ }^{\circledR}$ FCT dengan dosis $70 \mathrm{mg} / \mathrm{KgBB}$ dengan cara 7 tablet Curcuma ${ }^{\circledR}$ FCT yang tiap tablet mengandung ekstrak curcuma xanthorrhiza sebanyak $20 \mathrm{mg}$ dilarutkan dengan 5\% Tween 80 sampai $100 \mathrm{~mL}$. Larutan CCl4 5\%v/v dengan dosis $15 \mathrm{~mL} / \mathrm{KgBB}$ dengan cara $5 \mathrm{~mL} \mathrm{CCl}_{4}$ dilarutkan dalam olive oil hingga volume $100 \mathrm{~mL}$.

Larutan ekstrak etanol binahong dosis 35 $\mathrm{mg} / \mathrm{KgBB}, 70 \mathrm{mg} / \mathrm{KgBB}, 140 \mathrm{mg} / \mathrm{KgBB}$ (A. scandens (L.) Moq dengan cara ekstrak etanol binahong (A. scandens (L.) Moq.ditimbang sebanyak $140 \mathrm{mg}, 280 \mathrm{mg}, 560 \mathrm{mg}$ masing masing dilarutkan dengan larutan 5\% Tween 80 sebanyak $100 \mathrm{~mL}$.

\subsubsection{Uji Aktivitas Hepatoprotektor}

Mencit diadaptasikan selama 1 minggu setelah itu diberi perlakuan sekali sehari selama 7 hari. Setelah 48 jam perlakuan hewan uji dikorbankan, kemudian dibagi menjadi 6 kelompok. Kelompok K0 sebagai kontrol normal diberi 5\% Tween 80 di hari ke 1-6 dan Olive oil pada hari ke-7, kelompok K1 sebagai kontrol positif diberi curcuma di hari ke 1-6 dan induksi $\mathrm{CCL}_{4}$ pada hari ke-7, kelompok $\mathrm{K} 2$ sebagai kontrol negatif diberi 5\% Tween 80 di hari ke 1-6 dan $\mathrm{CCL}_{4}$ pada hari ke-7. Pemberian ekstrak etanol binahong dengan dosis $35 \mathrm{mg} / \mathrm{kgBB}, 70 \mathrm{mg} / \mathrm{kgBB}$ dan $140 \mathrm{mg} / \mathrm{kgBB}$ di hari ke 1-6 untuk kelompok perlakuan I, II dan III dan hari ke 7 diberi $\mathrm{CCL}_{4}$. Setelah 48 jam perlakuan seluruh mencit di kobarkan dan diambil heparnya setelah itu dibuat preparat histopatologi, untuk penilaian mikroskopik. Pemeriksaan preparat sel hati mencit hasil pengecatan hematoxilin-eosin dilakukan dengan mikroskop dengan perbesaran $100-400$ kali dengan menggunakan rumus $\mathrm{Z}$ (5lapang pandang setiap preparat) (Kawasaki dkk, 2009). Hasil pemeriksaan dibuat fotomikroskopis sebagai data kualitatif. Pemeriksaan histologi sel hati dilakukan di Laboran Balai Balai Besar Veteriner (BB-Vet) .

Tabel.1 Skor Derajat Kerusakan Sel Hati Mencit (Putra , 2009)

\begin{tabular}{cl}
\hline Skor & \multicolumn{1}{c}{ Jenis Kerusakan Sel Hati Mencit } \\
\hline 0 & Tidak ada perubahan (normal) \\
1 & Ditemukan degenerasi hidrofik $(\mathrm{dh})$ \\
2 & Ditemukan degenerasi melemak $(\mathrm{dm})$ \\
3 & Ditemukan nekrosis (nk) \\
\hline
\end{tabular}

Tabel 2.Skor Jumlah Kerusakan Hati (Kawasaki dkk, 2009)

\begin{tabular}{cl}
\hline Skor & Jenis Kerusakan Sel Hati Mencit \\
\hline 0 & Tidak ada kerusakan \\
1 & Jumlah kerusakan $<20 \% *$ \\
2 & Jumlah kerusakan $20-40 \% *$ \\
3 & Jumlah kerusakan $41-60 \% *$ \\
4 & Jumlah kerusakan $61-80 \% *$ \\
5 & Jumlah kerusakan $81-100 \% *$ \\
\hline Keterangan: * = Penentuan persen kerusakan ditentukan \\
\\
dengan cara membandingkan terhadap \\
kelompok dengan kerusakan tertinggi.
\end{tabular}


Skor total derajat kerusakan hati ditentukan dengan persamaan:

$\begin{aligned} \text { Skor total = } & \text { (skor jenis kerusakan dh } x \text { skor } \\ & \text { jumlah kerusakan })+(\text { skor jenis } \\ & \text { kerusakan dm } x \text { skor jumlah } \\ & \text { kerusakan) }+\quad \text { ( skor jenis } \\ & \text { kerusakan nk } x \text { skor jumlah } \\ & \text { kerusakan) }\end{aligned}$

Keterangan :

$\mathrm{dh}=$ degenerasi hidrofik; $\mathrm{dm}=$ degenerasi melemak; $\mathrm{nk}=$ nekrosis

Persen perbaikan histologi hati detentukan dengan persamaan:

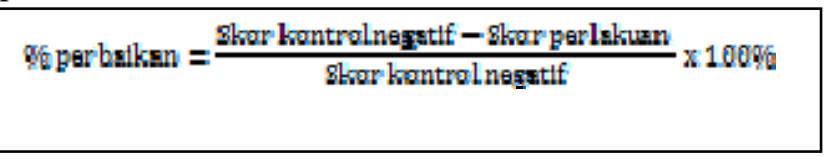

\section{HASIL DAN PEMBAHASAN}

Presentasi skor kerusakan hati dan proteksi perbaikan terhadap hati dari hewan uji sebagai berikut. Gambar 1 menunjukkan bahwa adanya pengaruh terhadap presentasi perbaikan hati pada kelompok perlakuan ekstrak uji dibandingkan dengan kontrol negatif. Kelompok perlakuan III memiliki nilai rata- rata skor kerusakan hati yang paling rendah dan persen perbaikan histologis hati yang paling tinggi dibandingkan kelompok perlakuan lainnya yaitu sebesar $11.83 \pm 2.78$ dan $52.67 \pm 11.147 \%$. Persen perbaikan histologis hati menunjukkan persentase selisih derajat kerusakan hati dibandingkan kelompok kontrol negatif. Persen proteksi untuk kelompok perlakuan I dan II secara berturut-turut sebesar $41.33 \pm 17.64 \%$ dan $51.40 \pm 8.547 \%$. Turunnya derajat kerusakan hati dan meningkatnya persen perbaikan histologi hati pada kelompok perlakuan tersebut mengindikasikan bahwa ekstrak etanol Binahong mampu mencegah terjadinya kerusakan histologi hati.

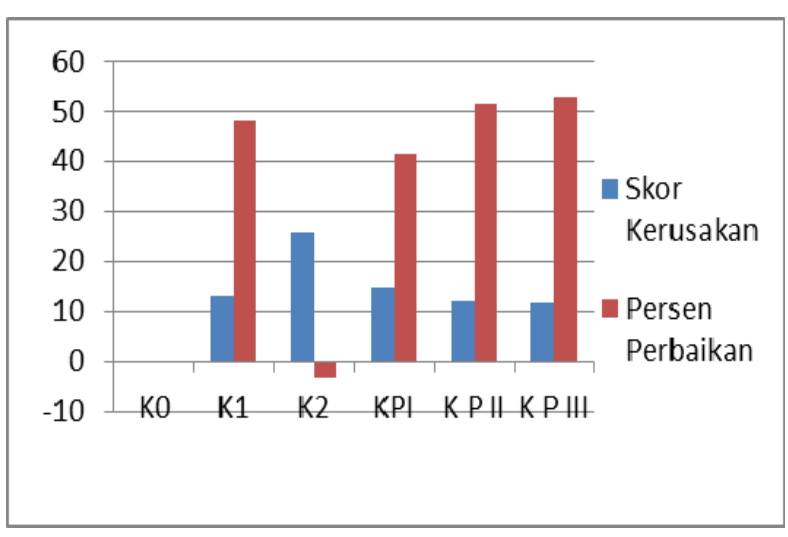

Gambar 1. Presentasi Skor Kerusakan Hati dan Persen Perbaikan

Keterangan : $\mathrm{K} 0=$ kelompok normal; $\mathrm{K} 1=$ kelompok positif; $\mathrm{K} 2=$ kelompok negatif; KPI = kelompok pelakuan 1; KPII = kelompok perlakuan 2;

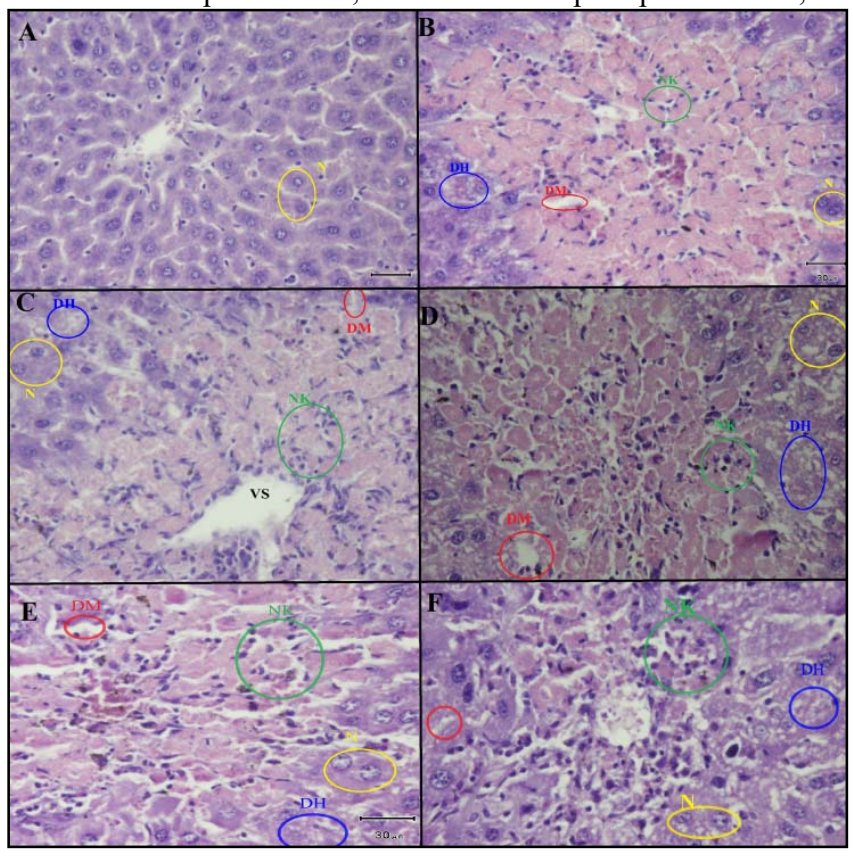

$\mathrm{KPIII}=$ kelompok perlakuan

Gambar 2. Gambar Histopat masing - masing kelompok

Keterangan : $\mathrm{A}=$ Gambar histopat kontrol normal; $\mathrm{B}=$ Gambar histopat kontrol positif; $\mathrm{C}=$ Gambar histopat kontrol negatif, $\mathrm{D}=$ Gambar histopat perlakuan I, E= Gambar histopat perlakuan II, $\mathrm{F}=$ Gambar histopat perlakuan III; $\mathrm{N}=$ Normal; $\mathrm{DH}=$ Degenerasi hidrofik; $\mathrm{DM}=$ Degenerasi melemak; NK $=$ Nekrosis, VS $=$ Vena Sentralis 


\section{KESIMPULAN}

Pada pemberian ekstrak etanol daun binahong (Anredera scandens (1.) moq.) terhadap histopatologi hati mencit jantan galur balb/c yang diinduksi dengan karbon tertraklorida bahwa secara hitopatologi adanya perbaikan terlihat dari peningkatan persen perbaikan pada kelompok perlakuan yang ditandai dengan turunnya skor kerusakan hati dan meningkatkannya persen kerusakan hati pada kelompok perlakuan.

\section{UCAPAN TERIMA KASIH}

Penulis mengucapkan terima kasih yang setulus-tulusnya kepada semua pihak yang telah membantu penelitian ini serta Kementran Riset, Teknologi, dan Pendidikan Tinggi telah memberikan dana PKM sehingga penelitian ini terlaksana.

\section{REFERENSI}

Cinthya, S.E., Ivan, S.P., dan Rizky, A. 2012. Penggunaan Obat Penginduksi Kerusakan Hati pada Pasien Rawat Inap Penyakit Hati di Salah Satu Rumah Sakit di Kota Tasikmalaya. Jurnal Farmasi Klinik Indonesia. Tasikmalaya.1(2).

DepKes RI. 2007.Pharmaceutical Care Untuk Penyakit Hati. Direktorat Bina Farmasi Komunitas dan Klinik Ditjen Bina Kefarmasian dan Alat Kesehatan. Jakarta: Departemen Kesehatan RI.

Fitria, A. 2009. Uji Aktivitas Antibakteri Ekstrak Daun Anredera cordifolia (Ten.) Steen,Anredera scandens (L.) Moq., Basella rubra L. pada Bakteri Gram Positif dan Bakteri Negatif (Skripsi). Denpasar: Universitas Udayana.

Karismawan, P. N. 2013. Profil Kandungan Kimia dan Uji Aktivitas Antiluka Bakar Ekstrak Etanol Daun Binahong (Anredera scandens(L.) Moq.) Pada Tikus Jantan Galur Sprague Dawley. Skripsi. Bukit Jimbaran: Jurusan Farmasi Fakultas MIPA Universitas Udayana.

Kawasaki T, Igarashi K, Koeda T, Sugimoto K, Nakagawa K, Hayashi S, dkk. 2009. Rats fed fructose-enriched diets have characteristics of nonalcoholic hepatic

steatosis. $J$

Nutr.139(11):2067-71.

Klaasen, C.D.,and J.B. Watkins. 2003. Essential of Toxicology. USA: McGraw- Hill.

Lestari. D., Elin. Y. S. and Irda F. 2015. Anredera cordifolia Leaves as Antihyperlipidemmia and Endothelial Fat Content Reducer in male Wistar rat. Internasional Journal of Pharmaceutical and clinical Research. Vol.7(6):435-439

Linawati,Y., Reny,K., I.A.Donatus, 2003, Efek Hepatoprotektif Infus Daging BuahMakuto Dewo (Phaleria macrocarpa (Scheff.) Boerl) pada Mencit Jantan Terinduksi $\mathrm{CCl}_{4}$, dalam Risalah Seminar Ilmiah Nasional 28 Juni 2003. Yogyakarta:

FakultasFarmasi Universitas Sanata Dharma.

Noer, H.M.S., S. Waspadji, A.M. Rachman, L.A. Lesmana, D. Widodo, H. Isbagio, I. Alwi, dan U.B. Husodo. 1996.Buku Ajar Ilmu PenyakitDalam.Jakarta: Balai Penerbit FKUI.

Orbayinah, S dan Adhita K., 2003, Efikasi Binahong (Anredera cordifolia (Tenore) Steenis) terhadap Kadar Alkaline Phosphatase, Mutiara Medika, 8(2): 89-95.

Putra, A. A. G.Y. 2007. Skrining Fitokimia dan Uji Hepatoprotektif Infusa Daun Kesumba (Bixa orellana. L.) pada Mencit jantan Terinduksi Karbon Tertraklorida. Skripsi. Bukit Jimbaran :Jurusan Farmasi Fakultas MIPA, Universitas Udayana.

Samirana, P. O., N. P. E. Leliqia, and N. P. Ariantari. 2014. TLC-Densitometer Profile and Antiulcer Activity Assay of Ethanol Extract of Binahong Leaves (Anredera Scandens (L.) Moq.) in Sprague Dawley Strain Male Rats. Proceeding The International Conference of Pharmaceutical Care. Pp. 63-71

Winarsi,H.2007. Antioksidan Alami dan Radikal Bebas. Yogyakarta:Penerbit Kanisi. 